\title{
Retrospective Analysis of Short Term Outcomes with ab interno Gel Implant in the Treatment of Open Angle Glaucoma
}

\author{
Açık Açılı Glokom Tedavisinde ab interno Jel İmplant Kısa Dönem \\ Sonuçlarının Retrospektif İncelenmesi
}

\author{
Funda DiKKAYA ${ }^{1}$ (D), Mehmet Selim KOCABORA ${ }^{1}$ (D), Cemil YILMAZLI $^{2}$ (D), Sevil Karaman ERDUR ${ }^{1}$ (D), \\ Arzu AȘICl${ }^{2}$ \\ ${ }^{1}$ Medipol University School of Medicine, Department of Ophthalmology, Istanbul, Turkey \\ 2 Istanbul Eye Hospital, Istanbul, Turkey \\ ORCID ID: Funda Dikkaya 000000032312 2521, Mehmet Selim Kocabora 0000-0001-5335-3860, Cemil Yılmazlı 0000-0002-9196-7131, \\ Sevil Karaman Erdur 000000019829 7268, Arzu Așıcı 0000000253850039
}

Cite this article as: Dikkaya F, Kocabora MS, Yılmazlı C, Karaman Erdur S, AșıCı A. Retrospective Analysis of Short Term Outcomes with ab interno Gel Implant in the Treatment of Open Angle Glaucoma. Med J West Black Sea. 2021;5(2):137-142.

Corresponding Author

Funda Dikkaya

E-mail

fundadikkaya@hotmail.com

Received

23.09.2020

Revision

26.03.2021

Accepted

02.04.2021

\begin{abstract}
Aim: To evaluate the intraocular pressure (IOP) lowering and safety profiles of the Xen45 Gel Stent implantation with preoperative Mitomycin $\mathrm{C}$ injection during a 6 months follow-up in patients with primary open-angle glaucoma (POAG).

Material and Methods: Records of fourteen eyes of 13 POAG patients who underwent surgery with XEN45 Gel Stent combined with phacoemulsification were evaluated retrospectively. IOP changes, all complications and additional procedures during follow-up period were evaluated. Primary outcome measure was IOP, and the IOP target for complete success was defined as a postoperative IOP drop of more than $20 \%$ from preoperative baseline and $I O P \geq 6$ and $\leq 21$ at 6 months without any glaucoma medications and qualified success was defined as a postoperative IOP reduction of more than $20 \%$ and $I O P \geq 6$ and $\leq 21$ at 6 months with or without medications.

Results: Mean preoperative medicated IOP was $28.4 \pm 2.7 \mathrm{mmHg}$ with a mean of $2.6 \pm 0.6$ topical antiglaucoma molecules. After 6 month follow-up period, mean IOP decreased to $17.8 \pm 1.5 \mathrm{mmHg}$ (mean IOP reduction of $37 \%$ ) on $0.4 \pm 1.1$ antiglaucoma molecules. The complete success rate after 6 months was achieved in $42.8 \%$ and qualified success in 85.7 . Totally only $2(14.2 \%)$ patients required additional procedure (1 needling and 1 trabeculectomy).

Conclusion: The study showed that the XEN45 Gel Stent implantation combined with phaco-cataract surgery is an effective surgical method in POAG in case of uncontrolled IOP with a favorable safety profile and low complication rate.
\end{abstract}

Keywords: Glaucoma, Glaucoma drainage implants, Surgery

Öz

Amaç: Primer açık açılı glokom (PAAG) hastalarında 6 aylık takip sırasında preoperatif Mitomycin C enjeksiyonu ile Xen45 Jel Stent implantasyonunun göz içi basıncını(GiB) düşürme ve güvenlik profillerini değerlendirmek.

Gereç ve Yöntemler: Fakoemülsifikasyon ile kombine XEN45 Jel Stent ile ameliyat edilen 13 PAAG hastasının 14 gözünün kayıtları retrospektif olarak değerlendirildi. Takip süresince GiB değişiklikleri, tüm komplikasyonlar ve ek işlemler değerlendirildi. Çalışmada birincil değerlendirilen sonuç GiB idi. Tam başarı için belirlenen GỉB hedefi ameliyat öncesine göre \%20'nin üzerinde bir düşüş ve herhangi bir glokom ilacı olmaksızın 6 . ayda $\mathrm{GiB} \geq 6$ ve $\leq 21$ olarak tanımlandı. Yeterli başarı ise ilaçlı veya ilaçsız olarak 6. ayda GiB'de \%20'den fazla azalma ve GiB $\geq 6$ ve $\leq 21$ olarak tanımlandı. 
Dikkaya F et al.

Bulgular: Ortalama preoperatif ilaçı GiB, ortalama 2,6 $\pm 0,6$ topikal anti-glokom molekülü ile beraber 28,4 $\pm 2,7 \mathrm{mmHg}$ idi. Altı aylık takip süresinden sonra ortalama GiB, 0,4 $\pm 1,1$ anti-glokom molekülü ile beraber 17,8 $\pm 1,5 \mathrm{mmHg}$ 'ye (ortalama GiB düşüşü \%37) düştü. 6 ay sonra tam başarı oranı $\% 42,8$ ve yeterli başarı oranı $\% 85,7$ olarak bulundu. Toplamda sadece 2 hastaya $(\% 14,2)$ ek işlem $(1$ iğneleme ve 1 trabekülektomi) gerekti.

Sonuç: Çalışma, fako-katarakt cerrahisi ile kombine XEN45 Jel Stent implantasyonunun, kontrolsüz GiB durumunda olumlu güvenlik profili ve düşük komplikasyon oranı ile PAAG'da etkili bir cerrahi yöntem olabileceğini göstermiştir.

Anahtar Sözcükler: Glokom, Glokom drenaj implantları, Cerrahi

\section{INTRODUCTION}

Glaucoma is worldwide the second cause of blindness. The estimated number of glaucomatous people on the entire world is 80 million by 2020,112 million in 2040 and $74 \%$ of these will be open angle glaucoma $(1,2)$. Most of the glaucoma patients is controlled by medications on the other hand the issues as poor patient compliance, allergical and toxic reactions are the main reasons necessitating a surgical approach.

Subconjunctival drainage of aqueous is the most effective method of achieving sustained IOP reduction and traditionally trabeculectomy is the gold standard surgical method for lowering intraocular pressure but it involves complications including hypotony, bleb leakage, subconjunctival fibrosis (3). For this reason, recently minimal invasive glaucoma surgery techniques have been developed to decrease the rate of complications. Minimal invasive glaucoma surgery via ab interno incision (from clear cornea) avoids conjunctival dissection and minimizes tissue trauma those aims to provide a safer and less invasive reduction of intraocular pressure (IOP) than traditional surgery.

$\mathrm{Ab}$ interno placement of Xen gel stent in subconjunctival space is an alternative surgical method as a safe minimal invasive procedure. The Xen Gel implant is made from crosslinked collagen gelatin $(4,5)$. It is highly biocompatible and hydrophilic in contrast to the silicone used in setons $(5,6)$. Current Xen model, Xen45 (Allergan, CA,USA) have been designed based upon the Hagen-Poiseuille equation and is $6 \mathrm{~mm}$ in length with 45 micron internal lumen diameter providing 6-8 $\mathrm{mmHg}$ of outflow resistance, which essentially eliminates hypotony. It is inserted ab interno through a small corneal incision sparing the conjunctiva and it creates a flow pathway from the anterior chamber to the subconjunctival space, bypassing the resistance of the trabecular meshwork and collector channels (6).

The purpose of this retrospective study is to evaluate the IOP lowering and safety profiles of the Xen 45 implantation with preoperative Mitomycin $\mathrm{C}$ injection during a 6 months follow-up in patients with open-angle glaucoma.

\section{MATERIALS and METHODS}

The present study was approved by the local medical ethical committee and was in accordance with the tenets in the Declaration of Helsinki.
Records of fourteen eyes of 13 consecutive primary open angle glaucoma (POAG) patients who underwent surgery with XEN45 Gel stent combined with phacoemulsification were evaluated retrospectively. All patient had complete clinical examination comprising best corrected visual acuity (BCVA), Goldmann applanation tonometry (AT 900, Haag Strait, Germany), slit-lamp biomicroscopy, gonioscopy, retinal nerve fiber thickness and macular analysis with optical coherence tomography (OCT) (Heidelberg Engineering, Heidelberg, Germany), 30-2 automatic perimetry (Zeiss Humphrey, Dublin, CA, USA) and dilated fundus examination.

All of the eyes had high IOP $(>21 \mathrm{mmHg}$ ) despite maximal tolerated topical medication with no prior surgery or laser and with a healthy and mobile conjunctiva. Exclusion criteria included angle closure, congenital, neovascular or pseudoexfoliative glaucoma, history of uveitis and prior ocular surgery.

All eyes received a XEN45 stent to superior nasal quadrant combined with phaco-cataract surgery. Preoperatively in each eye, superior nasal conjunctiva was marked 3 $\mathrm{mm}$ from the limbus and $0.2 \mathrm{ml}$ of $0.1 \mathrm{mg} / \mathrm{ml}$ Mitomycin C (MMC) was injected subconjunctivally using a $30 \mathrm{G}$ needle and spread with microsponge 10 minutes before phacoemulsification starts. After the cataract operation a single suture was applied to the main incision and the anterior chamber (AC) was filled with viscoelastic material then the preloaded injector needle was inserted through a corneal $20 \mathrm{G}$ incision at inferior temporal quadrant, the needle was then directed across the AC and the Xen45 stent implanted in the superior nasal quadrant. The implant is placed into the subconjunctival space exiting through the sclera at $3.0 \mathrm{~mm}$ posterior to the limbus. $1-2 \mathrm{~mm}$ of the implant is left in the AC. At the end, viscoelastic material was removed. Postoperative treatment included prednizolone asetat 1\% (Pred forte; Allergan) and moxifloxacin $0.5 \%$ (Vigamox; Alcon) given five times daily for one week and then tapered depending on postoperative progress. Antiglaucoma medication was stopped after surgery. Figure 1 (A) shows appearance of the subconjunctival pathway of Xen, (B) shows Xen device in the anterior chamber and (C) shows intrascleral part by anterior segment-OCT.

Follow-up examinations were conducted at 1 day, 1 week, and 1,3 , and 6 months. IOP changes, all complications and additional procedures during follow-up period were 
evaluated. Resumption of IOP-lowering medications after surgery was depended on each patient's target IOP range.

Primary outcome measure was IOP, and the IOP target for complete success was defined as a postoperative IOP drop of more than $20 \%$ from preoperative baseline and $I O P \geq 6$ and $\leq 21$ at 6 months without any glaucoma medications and qualified success was defined as a postoperative IOP reduction of more than $20 \%$ and $I O P \geq 6$ and $\leq 21$ at 6 months with or without medications.

\section{Statistical Analysis}

All statistical analysis was performed using SPSS Version 22.0 (SPSS Inc., Chicago, IL, USA). The mean of the last 2 measured IOP when the indication for surgery was set named as baseline IOP. The normality of the continuous variables was evaluated with the Shapiro-Wilk test. Descriptive statistical methods (mean, standard deviation) were used to evaluate the data and IOP measurements were compared using Friedman test. A p value of less than 0.05 was considered statistically significant. When a significant difference found by Friedman test, post hoc analysis with Wilcoxon signed-rank tests was conducted with a Bonferroni correction applied. The cumulative probability of success was assessed using Kaplan-Meier survival curves, with complete success defined as a postoperative IOP drop of more than $20 \%$ from preoperative baseline and IOP $\geq 6$ and $\leq 21$ at 6 months without any glaucoma medications and qualified success was defined as a postoperative IOP reduction of more than $20 \%$ and $I O P \geq 6$ and $\leq 21$ at 6 months with or without medications.

\section{RESULTS}

Fourteen eyes of 13 consecutive primary open angle glaucoma (POAG) patients ( 6 female, 7 male) with the mean age of $67.5 \pm 5$ years (median: 68.5 years, range: 55-79 years) were included in the study. The mean best corrected visual acuity was $0.26 \pm 0.12$ preoperatively and $0.07 \pm 0.08$ postoperatively with logMAR acuity testing $(p=0.001)$. All patients completed at least six months of follow-up. Mean preoperative medicated IOP was $28.4 \pm 2.7 \mathrm{mmHg}$ (median:
$28.5 \mathrm{mmHg}$, range: $25-34 \mathrm{mmHg}$ ). During the 6 month follow-up period, mean IOP decreased to $13.8 \pm 2.4 \mathrm{mmHg}$ (median: $14 \mathrm{mmHg}$, range: $10-18 \mathrm{mmHg}$ ) in the first day, $13.6 \pm 1.9 \mathrm{mmHg}$ (median: $14 \mathrm{mmHg}$, range: $10-17 \mathrm{mmHg}$ ) at first week, $18.6 \pm 4.2 \mathrm{mmHg}$ (median: $18 \mathrm{mmHg}$, range: 13-28 mmHg) at first month, $18.7 \pm 3.5 \mathrm{mmHg}$ (median:19.5 $\mathrm{mmHg}$, range: $14-27 \mathrm{mmHg}$ ) at third month and $17.8 \pm 1.5$ $\mathrm{mmHg}$ (median:18 $\mathrm{mmHg}$, range:15-20 $\mathrm{mmHg}$ ) at sixth month involving an IOP reduction of $51 \%, 52 \%, 34 \%, 34 \%$ and $37 \%$ respectively $(p<0.01$ at all-time points, except day 1 vs week 1 and month 3 vs month 6). The mean number of topical anti-glaucoma molecules decreased from a mean of $2.6 \pm 0.6$ (median: 3 , range: $2-4$ ) to $0.2 \pm 0.7$ (median: 0 , range: $0-3$ ) and $0.4 \pm 1.1$ (median: 0.5 , range: $0-1$ ) in the first month and sixth month respectively $(p<0.001)$. The complete success rate after 6 months was achieved in $42.8 \%$ (6 of 14 eyes) and qualified success in $85.7 \%$ (12 of 14 eyes). Kaplan-Meier survival curve analysis for complete and qualified success was shown in Figure 2. At 6th month $50 \%(7 / 14)$ of the eyes needed topical treatment and totally only $2(14.2 \%)$ patients required additional procedure (1 needling and 1 trabeculectomy). Needling with MMC was required to restore the drainage in one eye with cystic bleb formation 2 months after XEN implantation (Figure 3). One eye experienced serious hypertony which can not be controlled by medication at fourth month; thereafter a trabeculectomy was required for it. No major intraoperative events occurred except for transient AC hemorrhages in 1 eye while the needle passes through the angle. Postoperatively one case had mild inflammation in the anterior chamber which resolved with topical corticosteroid drop. Hypotony (IOP $\leq 6 \mathrm{mmHg}$ ) was not observed in the postoperative follow-up period. None of the patients had decrease in visual acuity compared to preoperative period. Table 1 represents the pre and post-operative results of each eye and Table 2 represents the mean values.

\section{DISCUSSION}

In this retrospective study, we evaluated the initial outcomes with XEN implantation combined with phaco-cataract surgery
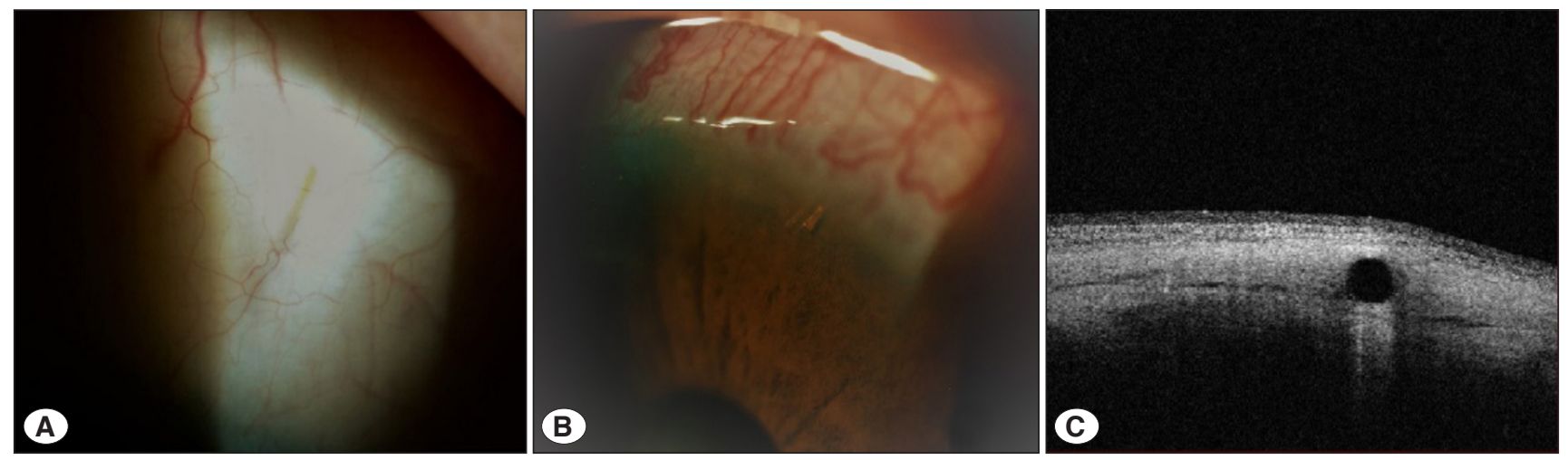

Figure 1: (A) Color photography showing appearance of the subconjunctival pathway of Xen Gel Stent implant (B) Color photography showing Xen Gel Stent in the anterior chamber (C) Anterior segment-OCT image showing intrascleral part of Xen implant. 


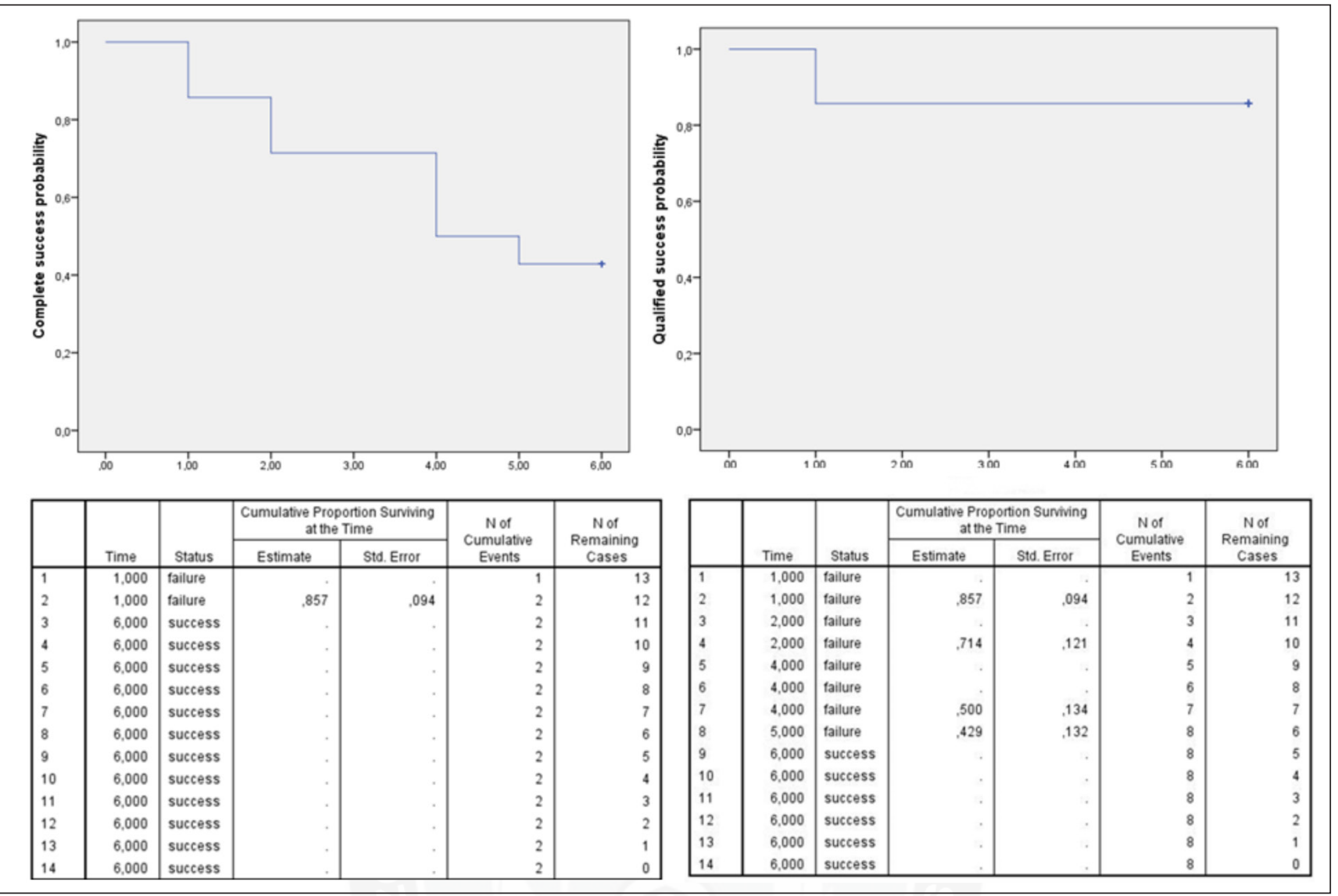

Figure 2: The Kaplan-Meier survival curves and tables for eyes achieving complete success (A) and qualified success (B).

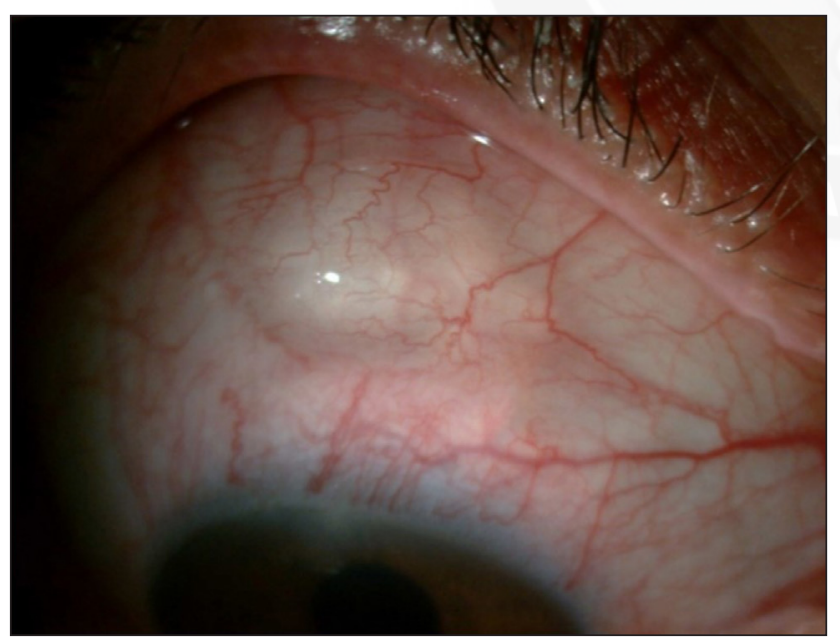

Figure 3: Color photography showing cystic bleb formation.

considering its IOP-lowering effect and complication rate. In our study, the XEN45 gel stent implantation combined with phaco-cataract surgery lowered IOP below $21 \mathrm{mmHg}$ in $85 \%(12 / 14)$ of cases and after a follow-up of 6 months the rate of reduction in mean IOP was $37 \%$. At 6th month $50 \%(7 / 14)$ of the eyes needed topical treatment and only 2
$(14,2 \%)$ patients required additional procedure (1 needling and 1 trabeculectomy).

Although trabeculectomy continues to be the gold standard for the surgical treatment of glaucoma, ophthalmologists are searching safe and minimal invasive methods to reduce IOP. Xen implant has been a one of these minimal invasive glaucoma surgery devices and mentioned in the literature with increasing number recently.

Perez-Torregrosa et al. reported IOP reduction of $31 \%$ at six months and $29.3 \%$ at 12 months with $94.5 \%$ decrease of number of medication. They only reported one $(3.3 \%)$ bleb encapsulation as a serious complication (7). De Gregorio reported the result of 41 primary open-angle and pseudoexfoliative glaucoma eyes underwent XEN implantation combined with cataract surgery. They found mean IOP reduction of $41.8 \%$ at 12 months with a mean of 0.4 medication classes. One patient had hypotony which spontaneously resolved in one week and 1 patient needed trabeculectomy after 1 month due to stent failure (8). Karimi et al. found a $26.4 \%$ reduction in IOP at 12 months from baseline which is lower than previous studies. They considered that this difference caused by including eyes with neovascular glaucoma, previous trabeculectomy or glaucoma drainage device which prognosis may have 
Table 1: Pre and post-operative results of each patient

\begin{tabular}{|c|c|c|c|c|c|c|c|c|c|c|c|c|}
\hline \multirow{2}{*}{ Eyes } & \multirow{2}{*}{ Age } & \multicolumn{2}{|l|}{ Baseline } & \multirow{2}{*}{$\begin{array}{c}1^{\text {st }} \text { day* }^{*} \\
\text { IOP }(\mathrm{mmHg})\end{array}$} & \multirow{2}{*}{$\begin{array}{c}1^{\text {st }} \text { week }^{*} \\
\text { IOP }(\mathrm{mmHg})\end{array}$} & \multicolumn{2}{|l|}{$1^{\text {st }}$ month } & \multicolumn{2}{|l|}{$3^{\text {rd }}$ month } & \multicolumn{2}{|l|}{$6^{\text {th }}$ month } & \multirow{2}{*}{$\begin{array}{l}\text { Additional } \\
\text { procedure }\end{array}$} \\
\hline & & IOP (mmHg) & $\mathbf{N}$ & & & IOP (mmHg) & $\mathbf{N}$ & IOP (mmHg) & $\mathbf{N}$ & IOP (mmHg) & $\mathbf{N}$ & \\
\hline 1 & 72 & 31 & 3 & 17 & 15 & 18 & - & 21 & 1 & 19 & 1 & - \\
\hline 2 & 59 & 29 & 3 & 14 & 14 & 17 & - & 20 & 1 & 19 & 1 & - \\
\hline 3 & 65 & 30 & 4 & 15 & 14 & 28 & 2 & 27 & 3 & 15 & - & TRAB \\
\hline 4 & 71 & 29 & 3 & 13 & 12 & 14 & - & 15 & - & 17 & - & - \\
\hline 5 & 64 & 27 & 2 & 12 & 12 & 13 & - & 14 & - & 17 & - & - \\
\hline 6 & 65 & 26 & 2 & 10 & 12 & 17 & - & 16 & - & 18 & - & - \\
\hline 7 & 66 & 28 & 2 & 16 & 15 & 19 & - & 21 & 1 & 19 & 1 & - \\
\hline 8 & 68 & 32 & 3 & 15 & 14 & 19 & - & 20 & 1 & 19 & 1 & - \\
\hline 9 & 79 & 30 & 3 & 18 & 17 & 20 & - & 21 & - & 18 & 1 & - \\
\hline 10 & 55 & 34 & 3 & 16 & 17 & 19 & - & 21 & 1 & 20 & 1 & - \\
\hline 11 & 72 & 25 & 2 & 12 & 14 & 15 & - & 15 & - & 15 & - & - \\
\hline 12 & 69 & 25 & 3 & 14 & 13 & 27 & 3 & 16 & 1 & 17 & 1 & Needling \\
\hline 13 & 70 & 26 & 2 & 10 & 12 & 17 & - & 17 & - & 18 & - & - \\
\hline 14 & 70 & 26 & 2 & 12 & 10 & 18 & - & 19 & - & 19 & - & - \\
\hline
\end{tabular}

*: No medication

IOP=intra ocular pressure, $\mathrm{N}=$ number of anti-glaucomatous molecules, TRAB=trabeculectomy

Table 2: Mean pre-operative and post-operative IOP and number of anti-glaucomatous molecule changes of the patients

\begin{tabular}{|c|c|c|c|c|c|c|c|c|c|c|c|}
\hline \multicolumn{3}{|c|}{ Baseline } & 1 st day & 1 st week & \multicolumn{2}{|c|}{1 st month } & \multicolumn{2}{|c|}{3 rd month } & \multicolumn{3}{|c|}{6 th month } \\
\hline 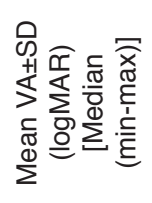 & 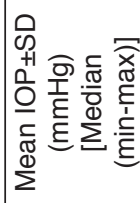 & 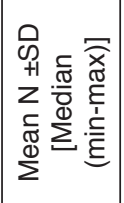 & 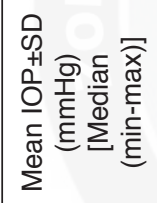 & 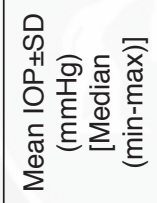 & 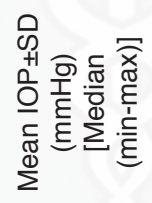 & 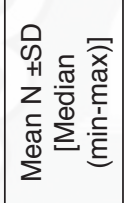 & 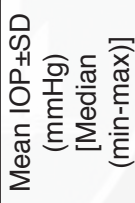 & 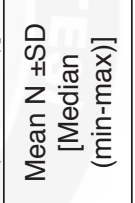 & 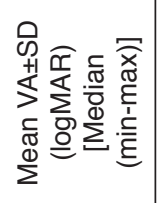 & 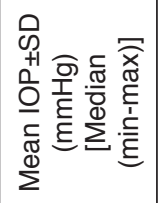 & 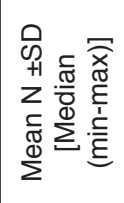 \\
\hline $\begin{array}{c}0.26 \pm 0.1 \\
{[0.26} \\
(0.09-0.52)]\end{array}$ & $\begin{array}{c}28.4 \pm 2.7 \\
{[28.5} \\
(25-34)]\end{array}$ & $\begin{array}{c}2.6 \pm 0.6 \\
{[3(2-4)]}\end{array}$ & $\begin{array}{r}13.8 \\
{[14(1}\end{array}$ & $\begin{array}{l}13.6 \\
{[14(}\end{array}$ & $\begin{array}{c}18.6 \pm 4.2 \\
{[18(13-28)]}\end{array}$ & $\begin{array}{l}0.2 \pm 0.7 \\
{[0(0-3)]}\end{array}$ & $\begin{array}{c}18.7 \pm 3.5 \\
{[19.5} \\
(14-27)]\end{array}$ & {$\left[\begin{array}{c}0.6 \pm 0.4 \\
{[0.5(0-3)]}\end{array}\right.$} & $\begin{array}{c}0.07 \pm 0.08 \\
{[0.04} \\
(0-0.3)]\end{array}$ & $\begin{array}{l} \pm 1.5 \\
5-20)]\end{array}$ & {$\left[\begin{array}{l}0.4 \pm 1.1 \\
{[0.5(0-1)]}\end{array}\right.$} \\
\hline \multicolumn{3}{|c|}{ p value* } & 0.001 & 0.001 & 0.001 & 0.001 & 0.001 & 0.001 & 0.001 & 0.001 & 0.001 \\
\hline
\end{tabular}

$\mathrm{VA}=$ Visual acuity, IOP=intra ocular pressure, $\mathrm{N}=$ number of anti-glaucomatous molecules

${ }^{*} p$ value comparing each time point with baseline values. (Friedman test, post hoc analysis with Wilcoxon signed-rank tests conducted with a Bonferroni correction)

been worse and in their report $40.9 \%$ of cases required postoperative bleb needling or antimetabolite injection which is also higher than other reports. They suggested that Xen implant may be good option for mild to moderate glaucoma. They also didn't find any statistical difference in IOP, number of anti-glaucoma medications, bleb needling rates or complications, when Xen implantation was performed with phacoemulsification or not (9).

In Mansouri et al's study which evaluates the result of 149 eyes, IOP had dropped to a mean $13.9 \pm 4.3 \mathrm{mmHg}$ (decrease of $-31 \%$ ) with $0.5 \pm 0.8$ medications at 12 months of follow-up and $28.7 \%$ of eyes required some anti-glaucoma medications for IOP reduction. Needling was performed in 55 eyes (37\%) which are higher than our study and there were only two cases (1.4\%) of hypotony. They used 0.1 $\mathrm{ml} \% 0.02 \mathrm{MMC}$ which has higher concentration and lower dosage than our study $(0.2 \mathrm{ml} \% 0.01 \mathrm{MMC})$. The higher number of patients, longer follow-up time and lower dosage of MMC may have led to higher needling rates. They both performed the XEN gel implant as a single procedure or combined with cataract surgery and demonstrated both has a favorable benefit/risk profile with a significant reduction in IOP (10). Galal et al. evaluated results of 13 eyes with POAG underwent XEN implantation and the percent of drop of IOP $21 \%$ and $23 \%$ at 6 and 12 months of follow-up. Mean number of medication decreased from $1.9 \pm 1$ to $0.3 \pm 0.4$ and 4 eyes $(30.7 \%)$ required needling during 12 months of follow-up. Two eyes had hypotony which were transient and responded to medical treatment (11). 
Hohberger et al. found $46.9 \%$ complete therapeutic success rate which was defined as IOP less than $18 \mathrm{mmHg}$ within 6 months of follow-up without topical antiglaucomatous therapy or additionally surgical interventions with single Xen Gel Stent implantation and 53.3\% with Xen + Phaco combined procedure in 111 open-angle glaucoma patients. Qualified success which was defined as IOP less than 18 $\mathrm{mmHg}$ with additional 1-2 local anti-glaucomatous eye drops was seen in $2.5 \%$ in the eyes of the single Xen Gel Stent implantation group and in $3.3 \%$ of the combined surgery group. These differences were not statistically significant (12).

Different MMC dosages and concentrations were used in the studies. While Perez-Torregrosa, De Gregorio and Galal et al. preferred $0.1 \mathrm{ml} 0.01 \% \mathrm{MMC}(7,8,11)$, Karim and Mansouri et al. preffered $0.1 \mathrm{ml} 0.02 \%$ MMC $(9,10)$. Different from these studies Hohberger et al. used higher concentration MMC $(0.1 \mathrm{ml} 0.03 \% \mathrm{MMC})(12)$. In the present study $0.1 \mathrm{ml} 0.02 \% \mathrm{MMC}$ was performed subconjunctivally. These concentration and dosage differences may have influenced the implant results.

The ab-interno implantation of the Xen 45 Gel Stents allows filtration directly into the subconjunctival space with protection of the conjunctiva thus reduces postoperative bleb related complications due to minimum conjunctival tissue damage and makes possible further glaucoma filtration surgeries to work. Another advantage is decrease risk of hypotony due to restricted aqueous flow. It seems to be an effective tool in glaucoma surgery to lower IOP with its IOP reduction rate from $23 \%$ to $41 \%(8,11)$.

Limitations of this study include small number of patients and short follow-up period. Also we only included primary open angle glaucoma patients. Success of the device with other type of glaucoma should also be investigated.

In conclusion, our study showed that the XEN45 gel stent implantation combined with phaco-cataract surgery is an effective surgical method in POAG in case of uncontrolled IOP despite topical medical therapy. At 1 month of implantation, maximum IOP lowering effect was reached. After this period if patients have high IOP, anti-glaucoma medication or filtration surgery should be planned. Moreover this new implant has a favorable safety profile with a low complication rate.

Acknowledgment

None.

Author Contributions

All contrbituions of each authors are equal.

Conflicts of Interest

The authors report no conflicts of interest. The authors alone are responsible for the content and writing of the paper.

\section{Financial Support}

This research did not receive any specifc grant from funding agencies in the public, commercial, or not-for-proft sectors.
Ethical Approval

The approval was obtained from the Non-Interventional Research Ethics Committee of Istanbul Medipol University (27.06.2018-354).

\section{Review Process}

This article is published with blind-review process and extremely review.

\section{REFERENCES}

1. Quigley HA, Broman AT. The number of people with glaucoma worldwide in 2010 and 2020. Br J Ophthalmol 2006;90:262267.

2. Tham YC, Li X, Wong TY, Quigley HA, Aung T, Cheng CY. Global prevalence of glaucoma and projections of glaucoma burden through 2040: A systematic review and meta-analysis. Ophthalmology 2014;121:2081-2090.

3. Watson PG, Jakeman C, Ozturk M, Barnett MF, Barnett F, Khaw KT. The complications of trabeculotomy (a 20-year follow-up). Eye (Lond) 1990;4:425-438.

4. Shute TS, Dietrich UM, Baker JFM, Carmichael KP, Wustenberg W, Ahmed IIK, Sheybani A. Biocompatibility of a novel microfistula implant in nonprimate mammals for the surgical treatment of glaucoma. Invest Ophthalmol Vis Sci 2016;57:3594-3600.

5. Lewis RA. Ab interno approach to the subconjunctival space using a collagen glaucoma stent. J Cataract Refract Surg 2014;40:1301-1306.

6. Sheybani A, Reitsamer H, K Ahmed IIK. Fluid dynamics of a novel micro-fistula implant for the surgical treatment of glaucoma. Invest Ophthalmol Vis Sci 2015;56:4789-4795.

7. Perez-Torregrosa VT, Olate-Pérez $A$, Cerdà-lbáñez $M$, Gargallo-Benedicto A, Osorio-Alayo V, Barreiro-Rego A, DuchSamper A. Combined phacoemulsification and XEN45 surgery from a temporal approach and 2 incisions. Arch Soc Esp Oftalmol 2016;91:415-421.

8. De Gregorio A, Pedrotti E, Russo L, Morselli S. Minimally invasive combined glaucoma and cataract surgery: Clinical results of the smallest ab interno gel stent. Int Ophthalmol 2018;38:1129-1134.

9. Karimi A, Lindfield D, Turnbull A, Dimitriou C, Bhatia B, Radwan M, Gouws P, Hanifudin A, Amerasinghe N, Jacob A. A multicentre interventional case series of 259 ab-interno Xen gel implants for glaucoma, with and without combined cataract surgery. Eye (Lond) 2019;33:469-477.

10. Mansouri K, Guidotti J, Rao HL, Ouabas A, D'Alessandro E, Roy S, Mermoud A. Prospective Evaluation of Standalone XEN Gel Implant and Combined Phacoemulsification-XEN Gel Implant Surgery: 1-Year Results. J Glaucoma 2018;27:140147.

11. Galal A, Bilgic A, Eltanamly R, Osman A. XEN Glaucoma Implant with Mitomycin C 1-Year Follow-Up: Result and Complicaitons. J Ophthalmol 2017;2017:5457246.

12. Hohberger B, Welge-Lüßen UC, Lämmer R. MIGS: Therapeutic success of combined Xen Gel Stent implantation with cataract surgery. Graefes Arch Clin Exp Ophthalmol 2018;256:621-625. 